\title{
Which Direction Is Forward: Perspectives on Rangeland Science Curricula
}

\author{
By T. L. Thurow, M. M. Kothmann, J. A. Tanaka, \\ and J. P. Dobrowolski
}

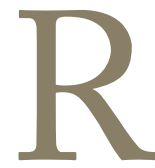

ange curriculum has been a long-standing subject of discussion within the rangeland management profession, ${ }^{1}$ dating back to the first formal curriculum suggestions published by Arthur Sampson in 1919. ${ }^{2}$ Throughout the history of this dialogue, it has been recognized that the knowledge passed on through university range curricula is an important influence on the capabilities of graduates entering the workforce and on the perspectives of new members and future leaders of the Society for Range Management (SRM). Therefore, as the organization representing range professionals, SRM has played and should continue to play an important role in shaping the future of the range profession. Continued interest in range curriculum content by the SRM membership demonstrates vitality within the profession and a commitment to progress.

A goal of past and current range curriculum discussions has been to balance depth and breadth of subject matter in ways that continue to provide core competencies while also being responsive to the changing nature of the public using rangeland resources and the need to integrate new knowledge and technology. Pursuit of this goal, which is very challenging in its own right, is increasingly complicated by the changing financial structure of universities. Over the past several decades, the US federal government has pursued a practice of shifting funding of land-grant universities from a baseline support formula to an increasing reliance on competitive research grants. Universities have responded to this change by shifting hiring priorities toward

This article has been peer reviewed. specialists who work on fundamental science topics capable of attracting large grants (which provide substantial indirect cost returns to the university). Therefore, since there is relatively little competitive grant support for managementoriented research, it is increasingly difficult to hire faculty who have the expertise and interest necessary to teach management-oriented courses. This trend is especially problematic because a large portion of current students do not come from rural settings where they may have acquired field experience. Another trend at universities is to merge programs with relatively low student enrollment into larger units ${ }^{3,4}$ in an attempt to save on administration costs. Consequently, very few stand-alone range departments remain, and there are a shrinking number of degree titles that include the word "range" or "rangeland." As disciplinary departments and degree titles are merged under broad banners such as "natural resources," "renewable resources," "ecosystem science and management," or "environmental sciences" (for a current list, see http://www.rangelands.org/ education_universities.shtml), there is a danger that the focus and resource allocation necessary to maintain a robust range curriculum may gradually dissipate.

These challenges are not unique to range programs. Many other disciplinary departments that have been traditionally maintained within universities, such as soils, forestry, and entomology, are subject to the same sort of trends. These changes matter because employers and the professional societies have a strategic interest in ensuring that students receive an education that blends both management and fundamental science. Administrators of the US Department of Agriculture Cooperative State Research, 
Education, and Extension Services (USDA-CSREES), the leadership of the SRM, and private and government employers recognize these national trends and have expressed concern about how to maintain a supply of range graduates capable of meeting the projected needs of employers. These concerns prompted a review of the SRM accreditation procedures for programs offering a degree in rangeland science. This resulted in the SRM updating the accreditation guidelines in 2006 in a manner that provided more flexibility for range programs to work with the changing dynamics of university administration, making the accreditation process inclusive of a broader array of departmental structures. The update also sought to make the accreditation procedure more outcome-oriented while continuing to ensure that sufficient depth and breadth of rangeland science education is provided by accredited academic programs. The Board of Directors of SRM is committed to conducting periodic review of the new accreditation standards with adjustments being made as deemed appropriate. This commitment is motivated by the recognition that it is vital that range programs maintain core skills development while also being responsive to changing societal needs and the evolving dynamics of university structure.

The current accreditation guidelines allow rangeland science education programs increased flexibility regarding the characteristics of the various aspects of required subject matter and the associated complementary mix of course work. It was recognized that this increased flexibility could enable rangeland programs to be responsive to unique challenges within their universities and the resource management needs of their regions. However, it was apparent through discussions associated with the accreditation revision process that there was a great diversity of viewpoints regarding the depth and breadth trade-offs associated with the formation of a modern range curriculum. How each range program deals with the subject matter depth and breadth trade-offs in revising a curriculum is ultimately central to the future character of range education and the evolving capabilities of the range professionals represented by SRM.

The goal of this study was to provide an analysis of what a group of SRM members perceive as the relative importance of various elements of rangeland science education. These data were also analyzed to determine how employment categories and personal values regarding the relative importance of rangeland products influenced perspectives on rangeland science education programs. These are appropriate and useful perspectives for academia to consider because the SRM membership represents a broad spectrum of rangeland managers, scientists, and educators whose experiences shape their insights regarding what skills are needed by effective rangeland stewards. This analysis can also help rangeland professionals to better appreciate the degree of shared and divergent viewpoints represented in the SRM membership.

\section{Methods}

In January 2007, a 4-page survey was mailed to 431 SRM members. The sample population was composed of all members who served on an SRM committee during 2006. The rationale for creating a sampling bias that targets this subgroup was that these people represent a cross section of SRM members who were especially likely to have been actively engaged in exchanging and analyzing current information regarding issues relevant to the various aspects of profession. A stamped, return-addressed envelope accompanied the survey; an exception was the 21 return-addressed envelopes mailed to non-US addresses that were not stamped because they required postage denominated in those countries. Twelve of the surveys could not be delivered by the Postal Service because the addresses were no longer valid. Therefore, the survey was delivered to 419 SRM committee members.

The first page of the 4-page survey provided an overview of the updated 2006 university rangeland science accreditation guidelines. The narrative explained that the accreditation guidelines are by necessity fairly broad, providing flexibility for each rangeland science education program with respect to their emphasis of subject matter. In this context, the survey was framed as seeking input to help guide academia regarding the knowledge base that a new graduate in range management would likely need on entering the workforce. The following 3 pages were survey questions (see tables in the "Results" section for the verbatim text of the questions).

In addition to the SRM survey, a survey was conducted at University of Wyoming where students were asked to respond to the same question on the SRM survey regarding their personal preference ranking of the importance of rangeland products. Unlike the SRM survey, the University of Wyoming survey was conducted by getting permission of instructors to use class time for a researcher to hand out the questionnaire and collect the responses. The classes were selected to generate a population survey proportionate to the enrollment in the different colleges. The distribution of survey respondents by college was Health Science 21\%, Physical and Biological Science $=17 \%$, Business $=15 \%$, Arts $=14 \%, \quad$ Agriculture $=14 \%, \quad$ Education $=13 \%$, and Engineering $=6 \%$, a population mix that was comparable to the actual enrollment distribution of University of Wyoming. In essence, the University of Wyoming survey is, therefore, a proxy for college-educated students from society in their age cohort.

Categorical analysis indicated that the data generated in response to many of the questions yielded a skewed, irregular bimodal pattern. To convey the degree and direction of how the responses are skewed relative to the entire sample population, the responses are presented so that the reader can simultaneously consider the mean (arithmetic average), median (midpoint of the data set), and mode (the most frequently chosen ranking). The amplitude of a 
bimodal distribution of ranked choices tends to become greater as the difference between mean and mode increases. The difference between the mode and median or mean increases as the number of responses skewed in one direction away from the mode increases.

\section{Results}

The survey population sampled the portion of SRM membership who, by virtue of their current, voluntary SRM committee service, have demonstrated their willingness to devote time in support of SRM activities. This characteristic and, perhaps, the level of interest in the survey topic likely contributed to the relatively high return rate (290 returns of 419 surveys [69\%]). For a return rate comparison, a 2006 survey of all SRM members regarding perceptions of the Rangelands publication received a $26 \%$ return rate from the over 3,000 e-mail and 500 paper-copy surveys sent; ${ }^{5}$ a 2002 survey of all SRM members seeking demographic data via electronic and paper media received a 30\% return rate. ${ }^{6}$

A profile of respondents' employment categories and the type of contact the respondents have with students or recent $\mathrm{BS}$ range science graduates is shown in Table 1 . The distribution of respondents to this survey differs from the occupation mix of the SRM membership as determined by the 2002 demographic survey. ${ }^{6}$ In particular, government agency personnel and university faculty represented, respectively, $55 \%$ and $27 \%$ of the respondents to the current survey, in contrast with $39 \%$ and $16 \%$ in the Albrecht survey. These data imply that representation on SRM committees may be populated by a disproportionately high number of members who are employed by government agencies or universities. Responses from consultants and ranchers were similar proportions to the Albrecht survey. Those listed in the "other" category (eg, students, retired) were $2 \%$ of the respondents to this survey but $25 \%$ of the Albrecht survey. These disparities likely reflect that those who volunteer for SRM committee service are disproportionately comprised of members who are currently employed. These disparities also imply that this survey population was more likely to be actively engaged in working with or teaching students and recent graduates than the general SRM membership.

In anticipation that individual perspectives regarding the relative importance of different rangeland products could influence judgment about what students should be studying, 2 questions were posed to determine the ranking of importance of various rangeland products from the respondents' point of view and from their assessment of what society wants from rangelands (Table 2). Analysis of this feedback indicated that the standard error of the mean responses to questions fell in the range of \pm 1.2 to 1.8 applied to

Table 1. Characteristics of survey respondents $(n=290)$. The job description survey question was "Please check which one of the following categories best describes your job description." The latest SRM membership job distribution is shown in the neighboring column for comparison. ${ }^{6}$ The type of contact with students question was "What is the character of contact you have with students who are currently pursuing their degree or have graduated with their B.S. degree within the past several years? (please check all that apply)"

\section{Job description}

Government agency

Resource manager

Researcher

University faculty

Private

\section{Consultant}

$$
\text { Rancher }
$$

Other (eg, student, retired)

\section{Type of contact with students (\%)}

Employment supervisor

University faculty

Employment coworker

No contact with students or recent graduates

\section{Respondent characteristics}

(\%)

\begin{tabular}{|l|l|}
\hline & $(\%)$ \\
\hline & 11 \\
\hline 27 \\
\hline \\
\hline 9 \\
\hline 7 \\
\hline 2 \\
\hline 44 \\
\hline 26 \\
\hline 16 \\
\hline
\end{tabular}

\section{SRM membership job description} (\%)

\begin{tabular}{|c|c|}
\hline & $(\%)$ \\
\hline 39 \\
\hline 16 \\
\hline 11 \\
\hline 25 \\
\hline
\end{tabular}


Table 2. Average score for ranked rangeland products. The irregular bimodal characteristic of many of the rankings is reflected by the amount and direction of spread between the mean $(\bar{X})$, median $(\mathrm{m})$, and mode (M). The various columns correspond to separate questions. The question posed for the first column $(n=286)$ was "Rangelands are valued for many reasons. Please rank the following rangeland products relative to their importance TO YOU (1 being most important; 6 being least important)." As a comparison, this same question was posed to University of Wyoming undergraduates (column $2 ; n=1,412){ }^{7}$ The question posed for the third column $(n=285)$ was "The value of rangeland products to you personally may be different from the multiple uses provided by rangelands to the overall society. Please rank the following products relative to your perception of their importance TO SOCIETY ( 1 being most important; 6 being least important)." The question posed for the fourth column $(n=280)$ was "What is your perception of how well rangeland science B.S. graduates are prepared to work with rangeland ecosystems and the people who use them in ways that will foster sustainable provision of each of these rangeland products? (rank as 1 being most prepared; 6 being least prepared)"

\begin{tabular}{|c|c|c|c|c|c|c|c|c|c|c|c|c|}
\hline \multirow[t]{2}{*}{$\begin{array}{l}\text { Rangeland } \\
\text { products }\end{array}$} & \multicolumn{3}{|c|}{$\begin{array}{l}\text { SRM member } \\
\text { ranking of product } \\
\text { importance to } \\
\text { themselves }\end{array}$} & \multicolumn{3}{|c|}{$\begin{array}{l}\text { University of } \\
\text { Wyoming student } \\
\text { ranking of product } \\
\text { importance to } \\
\text { themselves }\end{array}$} & \multicolumn{3}{|c|}{$\begin{array}{l}\text { SRM member } \\
\text { ranking of product } \\
\text { importance to } \\
\text { society }\end{array}$} & \multicolumn{3}{|c|}{$\begin{array}{l}\text { SRM member } \\
\text { ranking of which } \\
\text { products students } \\
\text { are most prepared } \\
\text { to manage with a } \\
\text { B.S. in rangeland } \\
\text { science }\end{array}$} \\
\hline & $\bar{x}$ & m & $\mathbf{M}$ & $\bar{x}$ & $\mathbf{m}$ & $\mathbf{M}$ & $\bar{x}$ & m & $\mathbf{M}$ & $\bar{x}$ & m & M \\
\hline Water & 2.5 & 2 & 2 & 2.2 & 2 & 2 & 2.5 & 2 & 1 & 3.7 & 4 & 3 \\
\hline $\begin{array}{l}\text { Existence } \\
\text { value }\end{array}$ & 2.7 & 2 & 1 & 2.9 & 3 & 3 & 2.9 & 2 & 1 & 3.4 & 3 & 1 \\
\hline Recreation & 4.4 & 5 & 5 & 3.6 & 3 & 4 & 3.1 & 3 & 2 & 4.2 & 4 & 4 \\
\hline Wildlife & 3.2 & 3 & 3 & 3.8 & 4 & 4 & 3.2 & 3 & 4 & 2.7 & 2 & 2 \\
\hline Livestock & 2.9 & 3 & 1 & 4.2 & 4 & 5 & 4.1 & 5 & 5 & 1.9 & 1 & 1 \\
\hline Timber & 5.0 & 6 & 6 & 4.3 & 4 & 5 & 5.2 & 6 & 6 & 4.9 & 5 & 6 \\
\hline
\end{tabular}

a possible score ranging from 1 (most important) to 6 (least important). This large variation was often attributable to an irregular bimodal distribution (ie, 2 peaks of different magnitudes) or a skewed distribution of the rankings. In particular, the importance of livestock and the importance of existence value (defined in the question in a very broad way to reflect an appreciation of the presence and aesthetics of healthy rangeland landscapes) tended to be ranked as very high or very low, resulting in relatively large standard errors for the means of both of these responses of \pm 1.7 . For example, livestock was ranked as being the most important rangeland product from a personal perspective by $26 \%$ of the respondents $(\operatorname{mode}=1)$, but there were also many respondents who ranked their personal perspective of livestock importance as a very low priority rangeland product, resulting in the median (3) and mean (2.9) being widely separated from the mode. Existence value was also evaluated to have a mode of 1 , with a median of 2 and a mean of 2.7.

Sometimes perspectives were diametrically opposed. For example, those who ranked recreation as 1 had a mode ranking of 6 for livestock, and those who ranked livestock as 1 had a mode ranking of 5 for recreation (Table 3 ). This may imply a perception that accommodation of the provision of one product impedes provision of the other.
Sometimes the responses were asymmetrical. For example, those who ranked livestock as 1 had a mode ranking of 5 for existence value, but those who ranked existence value as 1 had a mode ranking of 2 for livestock. This perhaps indicates that those who expressed a high ranking for existence value felt that this was compatible with properly managed livestock, whereas those who ranked livestock 1 felt that commodity production considerations have much greater importance than the existence value of the resource per se. This trade-off-commodity emphasis versus existence value - was reinforced in that those who ranked timber production as 1 had a mode-existence-value ranking of 6 .

Water was consistently ranked as a high priority rangeland product, regardless of what was ranked as personally most important (Table 3), resulting in water having the highest mean score (Table 2). Timber was consistently ranked as among the lowest-priority rangeland products, perhaps reflecting that even though some rangelands produce a lot of timber (eg, the Southeast and Northwest of the United States and some moderate-elevation ranges of the Rockies), most rangelands are considered by most respondents as marginal for timber production.

When asked to rank the importance of rangeland products to society, the 2 traditional marketed products 
Table 3. Ranking of rangeland products relative to the product that the respondents ranked as most important $(n=286)$. The irregular bimodal characteristic of many of the rankings is reflected by the amount and direction of spread between the mean $(\bar{X})$, median $(\mathrm{m})$, and mode $(\mathrm{M})$. The rankings are in response to the question "Rangelands are valued for many reasons. Please rank the following rangeland products relative to their importance TO YOU (1 being most important; 6 being least important)." Twelve respondents ranked several products as a \#1 ranking; hence, the sum of the \#1 rankings is greater than the number of respondents

\begin{tabular}{|c|c|c|c|c|c|c|c|c|c|c|c|c|c|c|c|c|c|c|}
\hline \multirow[t]{2}{*}{$\begin{array}{l}\text { Rangeland } \\
\text { product }\end{array}$} & \multicolumn{3}{|c|}{$\begin{array}{l}\text { Existence } \\
\text { value \#1 } \\
(n=113)\end{array}$} & \multicolumn{3}{|c|}{$\begin{array}{l}\text { Livestock } \\
\# 1(n=75)\end{array}$} & \multicolumn{3}{|c|}{$\begin{array}{c}\text { Water \#1 } \\
(n=74)\end{array}$} & \multicolumn{3}{|c|}{$\begin{array}{l}\text { Wildlife \#1 } \\
\quad(n=28)\end{array}$} & \multicolumn{3}{|c|}{$\begin{array}{c}\text { Recreation \#1 } \\
(n=10)\end{array}$} & \multicolumn{3}{|c|}{$\begin{array}{c}\text { Timber \#1 } \\
\quad(n=8)\end{array}$} \\
\hline & $\bar{x}$ & m & M & $\bar{x}$ & m & M & $\bar{x}$ & m & M & $\bar{x}$ & m & M & $\bar{x}$ & m & M & $\bar{x}$ & m & M \\
\hline $\begin{array}{l}\text { Existence } \\
\text { value }\end{array}$ & - & - & - & 4.1 & 4 & 5 & 3.2 & 3 & 2 & 3.1 & 3 & 3 & 2.4 & 2 & 2 & 3.4 & 4 & 6 \\
\hline Livestock & 3.4 & 3 & 2 & - & - & - & 3.3 & 3 & 3 & 3.6 & 4 & 5 & 4.1 & 5 & 6 & 3.3 & 3 & 1 \\
\hline Water & 2.8 & 3 & 2 & 2.9 & 3 & 2 & - & - & - & 2.9 & 3 & 3 & 2.5 & 2 & 1 & 2.9 & 3 & 4 \\
\hline Wildlife & 3.6 & 4 & 3 & 3.1 & 3 & 3 & 3.1 & 3 & 3 & - & - & - & 2.8 & 3 & 4 & 2.1 & 2 & 2 \\
\hline Recreation & 4.2 & 5 & 5 & 4.6 & 5 & 5 & 3.3 & 5 & 5 & 3.6 & 4 & 6 & - & - & - & 4.4 & 5 & 5 \\
\hline Timber & 5.3 & 6 & 6 & 4.5 & 5 & 6 & 4.9 & 6 & 6 & 4.7 & 5 & 6 & 3.7 & 4 & 5 & - & - & - \\
\hline
\end{tabular}

from rangelands-livestock and timber-received a mode ranking of 5 and 6 , respectively. Thus, while the ranking of personal importance resulted in a mode ranking of 1 for livestock, the respondents apparently felt that their personal perspective deviated from that of society, which they anticipated would have a mode ranking of livestock as 5 . Perceptions of the importance-to-society rankings of SRM respondents are very similar to the rankings of a general survey of University of Wyoming students $(n=1,412)$ responding to the same question asking them to rank the importance of rangeland products to themselves (Table 2). ${ }^{7}$ A response rate $99.3 \%$ was achieved for the University of Wyoming student survey since the surveys were conducted using a portion of class time to hand out and collect input. It is notable that the responses from the University of Wyoming student body reflected a normal (bell-shaped) distribution (ie, the mean, median, and mode were very similar) for their rankings of rangeland products important to them, whereas the SRM survey responses were often skewed and bimodal in their personal rankings of rangeland products.

When asked what activity recent rangeland science graduates are best prepared to work with on graduation, $66 \%$ of the supervisors and $60 \%$ of the faculty ranked students as best prepared to manage livestock (Table 4). It is interesting to note that a much lower percentage of coworkers ranked student preparation to work with livestock as highest (43\%), perhaps indicating a lower observed proficiency in managing for livestock than supervisors or faculty were anticipating. Survey ranking of what students were best prepared to manage was poorly correlated with the ranking of importance to University of Wyoming student body $(r=-0.09)$ and the SRM member ranking of rangeland products most important to society $(r=0.23)$ but was well correlated with SRM member ranking of product importance to themselves $(r=0.70)$. This might be expected since the curricula have been developed by professional rangeland managers and scientists.

The role of rangelands in either providing energy resources or sequestering carbon were dominant responses to an open-ended query concerning what products, in addition to the 6 asked about in the previous questions, should be considered when thinking of rangelands (Table 5). Only $26 \%$ of the respondents replied to this question.

Table 6 illustrates the mean ranking of skill levels needed for topics often covered in rangeland science curriculums. In general, the variance in the perception of skill level required increases as ranking of the importance of the skill drops. This indicates that there is greater unanimity among the respondents for subject-matter categories that are viewed as important or essential than there is for lower-ranking subject skills. As the variation for a particular skill category increased for skills that received lower scores, the variation can usually be explained by closer examination. For example, rankings for animal physiology/nutrition/behavior or ranch/farm management were positively correlated with individual rankings of livestock importance and less so for societal rankings $(r=0.44$ for individual value; $r=0.22$ for societal value; see Tables 2 and 3). Skill ranking correlations were consistently more strongly related with the ranking of the rangeland products most important to the respondent ( $r$ values tended to range from 0.2 to 0.4 ) rather than with the ranking of rangeland products judged to be most important to society ( $r$ values tended to range from 0.1 to 0.2 ). The variance in skill-level ranking was sometimes associated with the type of job the respondent held. For example, 
Table 4. Ranking of student preparation as perceived by the categories characterizing the nature of contact that the respondent has had with students who are currently pursuing their degree or have graduated with their B.S. degree within the past several years. The question was "What is your perception of how well are rangeland science B.S. graduates prepared to work with rangeland ecosystems and the people who use them in ways that will foster sustainable provision of each of these rangeland products? (rank as 1 being most prepared; 6 being least prepared)"

\begin{tabular}{|c|c|c|c|c|c|c|c|c|c|c|c|c|}
\hline \multirow[t]{2}{*}{$\begin{array}{l}\text { Rangeland } \\
\text { products }\end{array}$} & \multicolumn{3}{|c|}{$\begin{array}{l}\text { Supervisor } \\
(n=125)\end{array}$} & \multicolumn{3}{|c|}{$\begin{array}{c}\text { Coworker } \\
(n=47)\end{array}$} & \multicolumn{3}{|c|}{$\begin{array}{l}\text { Faculty } \\
(n=75)\end{array}$} & \multicolumn{3}{|c|}{$\begin{array}{l}\text { No recent contact } \\
\qquad(n=41)\end{array}$} \\
\hline & $\bar{x}$ & $\mathbf{m}$ & M & $\bar{x}$ & $\mathbf{m}$ & $\mathbf{M}$ & $\bar{x}$ & $\mathbf{m}$ & $\mathbf{M}$ & $\bar{x}$ & m & M \\
\hline Livestock & 1.8 & 1 & 1 & 2.3 & 2 & 1 & 1.8 & 1 & 1 & 2.1 & 1 & 1 \\
\hline Wildlife & 2.5 & 2 & 2 & 2.8 & 2 & 2 & 2.8 & 3 & 2 & 2.6 & 2 & 2 \\
\hline $\begin{array}{l}\text { existence } \\
\text { value }\end{array}$ & 3.5 & 3 & 3 & 3.0 & 3 & 1 & 3.4 & 3 & 1 & 3.6 & 3 & 3 \\
\hline Water & 3.7 & 4 & 3 & 3.3 & 3 & 3 & 3.5 & 3 & 3 & 4.2 & 5 & 5 \\
\hline Recreation & 4.1 & 4 & 4 & 4.3 & 4 & 4 & 4.4 & 5 & 5 & 3.7 & 4 & 4 \\
\hline Timber & 5.0 & 6 & 6 & 5.1 & 6 & 6 & 5.0 & 5 & 6 & 4.5 & 5 & 6 \\
\hline
\end{tabular}

statistics skills were ranked more important by faculty (3.0) and government researchers $(2.9)$ than by government land managers (2.2) or ranchers (2.0).

Responses to the open-ended question about what was most important for a rangeland science program to have provided to a student by the time they graduate are summarized in Table 7. The number of times subject matter was listed generally corresponds with the rankings shown in Table 6. Table 7 reflects a number of other descriptors that also reflect the values of the respondents. Values such as leadership, passion, or ethics are relatively poorly represented on this list, indicating in the context of the question that rangeland science programs are not very strongly associated with instilling these values in students.

When asked what was thought to be the appropriate percentage of time devoted to the 5 broad curricular categories (Table 8), there was a consistent relationship between the percentage of responses in each category in Table 7 and the percentages reported in Table 8. The variation associated with the mean rankings in the curriculum emphasis input can be partially understood by the job categories, with ranchers being the greatest outlier relative to their views of what should be emphasized in the curriculum. For example, ranchers suggested $46 \%$ curricula emphasis on resource management, whereas faculty suggested $28 \%$ for this category. The emphasis on resource management skills in university curriculum by ranchers is also reflected by the high percentage $(82 \%)$ of this group who indicated that natural resources work experience is essential (Table 9).

Most respondents believe that it is desirable that the word "range" or "rangeland" appear in the credential descriptor on the university transcript (Table 10). Approximately one-quarter of the respondents said that they thought that including such a term was essential. Conversely, less than $20 \%$ of the respondents thought such a term made little or no difference.

\section{Discussion}

A long-standing principle of SRM is that the priorities of rangeland management are expected to evolve in response to changing goals of society. This principle is reflected in the definition of range management as "the manipulation of rangeland components to obtain the optimum combination of goods and services for society on a sustained basis." ${ }^{8}$ This definition is also reflected by long-standing multiple-use goals for federal lands that mandate that resources be utilized in the combination that will best meet the needs of the American people. There has been a trend over the past several decades toward emphasis on existence value over commodity uses. This is reflected in the priorities in policies and implementation for threatened and endangered species, NEPA, and wilderness designation. Pursuit of "optimum" and "best" requires that land managers must make choices regarding inevitable trade-offs associated with a particular land management emphasis. Preparing students for a profession in rangeland management, therefore, requires that curriculums be designed to provide the depth and breadth of education appropriate for meeting societal goals for provision of rangeland goods and services. This implies that as societal goals for rangeland product provision change in emphasis, rangeland curricula should evolve to equip the students to respond to changing emphases of rangeland management.

"Optimum" and "best" reflect the values of society as a whole and in the absence of a market are susceptible to an array of creative interpretations. Personal values strongly 
Table 5. Number of responses to open-ended question that was posed as "Are there other rangeland products not included in the above list (livestock, existence value, recreation, timber/ wood, water, wildlife/fisheries) that you think should be considered? If so, please specify." Twenty-six percent of the respondents wrote something for this question $(n=74)$ with some listing several products

\section{Times listed by respondents}

\begin{tabular}{|l|c|}
\hline Ecosystem services & 23 \\
\hline Carbon sequestration & 8 \\
\hline Ecosystem services & 5 \\
\hline Air quality/air-shed & 5 \\
\hline Biodiversity conservation & 2 \\
\hline Waste disposal & \\
\hline Minerals and energy & 19 \\
\hline Minerals & 13 \\
\hline Fossil fuels & 9 \\
\hline Energy & 6 \\
\hline Wind energy & 4 \\
\hline Biofuel & 3 \\
\hline Solar energy & 1 \\
\hline Geothermal & \\
\hline Economics & \\
\hline Base of economic support for & 4 \\
\hline communities & 2 \\
\hline Real estate investment & \\
\hline Land conversion & 3 \\
\hline Suburban expansion & \\
\hline Transportation corridors & \\
\hline Croplands & \\
\hline Other products & \\
\hline Cultural/spiritual values & \\
\hline Food products & \\
\hline Medicinal products & \\
\hline Art products & \\
\hline Non-timber tree products & \\
\hline
\end{tabular}

influence what teachers choose to emphasize, they influence how researchers choose and design their study topics, and they influence the interpretation and implementation of management. Therefore, when seeking guidance from the
Table 6. Average score ( \pm SE) of skill level needed by professionals working in rangeland ecology and management $(n=289)$. The question as worded on the survey was "The following is a list of topics that are often covered as part of an education in rangeland science. Please circle a number to indicate the relative proficiency in each topic that a B.S. graduate in rangeland science would be likely to need in a rangeland management job, ranging between 1 (grasp of general concepts) and 5 (highly detailed proficiency) for each of the subject topics listed below. This feedback will provide guidance on the depth and breadth of education needed."

\begin{tabular}{|c|c|}
\hline \multirow[t]{2}{*}{ Subject } & $\begin{array}{l}\text { a job in rangeland } \\
\text { management }\end{array}$ \\
\hline & (1=low; $5=$ high $)$ \\
\hline Rangeland ecology & $4.6 \pm 0.6$ \\
\hline $\begin{array}{l}\text { Field inventory/assessment } \\
\text { methods }\end{array}$ & $4.5 \pm 0.7$ \\
\hline Plant identification/taxonomy & $4.3 \pm 0.8$ \\
\hline $\begin{array}{l}\text { Public interaction (listening/ } \\
\text { collaboration/mediation skills) }\end{array}$ & $4.3 \pm 0.8$ \\
\hline $\begin{array}{l}\text { Grazing systems } \\
\text { management }\end{array}$ & $4.1 \pm 0.9$ \\
\hline Technical writing & $4.0 \pm 0.9$ \\
\hline Watershed management & $3.9 \pm 0.8$ \\
\hline $\begin{array}{l}\text { Geographic information } \\
\text { science (GIS) }\end{array}$ & $3.9 \pm 0.9$ \\
\hline Public speaking & $3.9 \pm 0.9$ \\
\hline $\begin{array}{l}\text { Reclamation/restoration } \\
\text { techniques }\end{array}$ & $3.6 \pm 1.0$ \\
\hline Plant physiology & $3.6 \pm 1.1$ \\
\hline Wildlife management & $3.5 \pm 0.8$ \\
\hline Soil classification & $3.4 \pm 0.9$ \\
\hline Soil science & $3.4 \pm 1.0$ \\
\hline Integrated pest management & $3.4 \pm 1.0$ \\
\hline $\begin{array}{l}\text { Principles of general botany/ } \\
\text { biology }\end{array}$ & $3.3 \pm 1.2$ \\
\hline Natural resource policy/law & $3.2 \pm 1.1$ \\
\hline Ranch/farm management & $3.1 \pm 1.1$ \\
\hline $\begin{array}{l}\text { Animal physiology/nutrition/ } \\
\text { behavior }\end{array}$ & $3.0 \pm 1.1$ \\
\hline Economics & $2.9 \pm 1.0$ \\
\hline Recreation management & $2.7 \pm 0.9$ \\
\hline Forest management & $2.7 \pm 1.0$ \\
\hline Statistics & $2.7 \pm 1.0$ \\
\hline Sociology & $2.7 \pm 1.1$ \\
\hline Modeling & $2.3 \pm 1.0$ \\
\hline Environmental chemistry & $2.2 \pm 1.0$ \\
\hline
\end{tabular}


Table 7. Response to open-ended question that was posed as "Please list three things that you feel would be most important for a rangeland science program to have provided to a student by the time they graduate (ie, If a person has a B.S. degree in rangeland science, it would be reasonable to assume that the graduate understands and/or knows how to do ___"

\begin{tabular}{|c|c|}
\hline & $\begin{array}{c}\text { Times } \\
\text { listed by } \\
\text { respondents }\end{array}$ \\
\hline $\begin{array}{l}\text { Resource management (scientific } \\
\text { application and techniques) }\end{array}$ & $30 \%$ \\
\hline $\begin{array}{l}\text { Applied ecology/rangeland } \\
\text { management skills }\end{array}$ & 67 \\
\hline Develop management plans & 32 \\
\hline Practical work experience in field & 30 \\
\hline Watershed/riparian management & 26 \\
\hline Grazing systems/management & 23 \\
\hline Wildlife management & 19 \\
\hline Landscape management & 17 \\
\hline Restoration/reclamation techniques & 14 \\
\hline Livestock management & 13 \\
\hline Fire management & 7 \\
\hline Ranch/farm management & 7 \\
\hline Integrated multiple-use management & 7 \\
\hline Recreation management & 6 \\
\hline Invasive plant management & 5 \\
\hline Forest management & 4 \\
\hline Work ethic & 3 \\
\hline Sustainable management & 3 \\
\hline Integrated pest management & 3 \\
\hline $\begin{array}{l}\text { Holistic land/people/money } \\
\text { management }\end{array}$ & 3 \\
\hline Biodiversity management & 3 \\
\hline Adaptive management & 2 \\
\hline Air quality management & 1 \\
\hline Communication skills & $19 \%$ \\
\hline Communication skills (speaking/writing) & 106 \\
\hline $\begin{array}{l}\text { Public interaction skills (listening/ } \\
\text { diplomacy) }\end{array}$ & 50 \\
\hline Work in teams & 8 \\
\hline Conflict management & 7 \\
\hline Facilitation skills & 4 \\
\hline Leadership & 3 \\
\hline
\end{tabular}

Table 7. Continued

\section{Times \\ listed by respondents}

Appreciation of range profession

2

Passion for rangeland ecology and management

\section{Natural sciences (fundamental scientific processes)}

Ecosystem principles and processes

Plant identification

Foundation in basic sciences

Soil classification

Plant physiology

Plant/animal interaction

Livestock/wildlife interaction

Soil science

Soil/water/plant/animal interaction

Soil/plant interaction

Animal identification

Animal behavior

Animal physiology

Animal nutrition

\section{Quantitative skills}

Inventory/monitoring/assessment

Critical thinking skills

Assess rangeland condition/health

Assess succession/state and transition status

GIS/spatial analysis

Assess ecological site potential

Literature analysis

Computer skills

Statistics

Assess soil health

Social sciences (economics, sociology, policy, law)

Familiarity with natural resource policy/law

Applied economics

16

Personal ethics

8

Social science

6

Land ethics

5 
Table 8. Recommended percentage ( \pm SE) of curriculum emphasis devoted to each emphasis area. The question related to the first column $(n=287)$ was "There is a wide disparity in different range management programs regarding how much curriculum emphasis is provided relative to each of the five broad topic categories listed on the previous page. What would you consider to be the ideal percentage of a rangeland science instruction devoted to the various categories (please try to have them add to 100\%)?" The question related to the second column is a summary of feedback presented in Table 7

\begin{tabular}{|l|c|c|}
\hline $\begin{array}{l}\text { Desired } \\
\text { curriculum } \\
\text { emphasis } \\
\text { (\%); } \\
\text { percentage } \\
\text { estimate }\end{array}$ & $\begin{array}{c}\text { Desired } \\
\text { curriculum } \\
\text { emphasis } \\
\text { emp); } \\
\text { proportion } \\
\text { of written } \\
\text { comments }\end{array}$ \\
\hline $\begin{array}{l}\text { Resource } \\
\text { management } \\
\text { (scientific application } \\
\text { and technical skills) }\end{array}$ & $32 \pm 9.2$ & 30 \\
\hline $\begin{array}{l}\text { Natural sciences } \\
\text { (fundamental } \\
\text { scientific processes) }\end{array}$ & $27 \pm 10.3$ & 24 \\
\hline $\begin{array}{l}\text { Communication skills } \\
\text { Quantitative skills }\end{array}$ & $16 \pm 6.2$ & 19 \\
\hline $\begin{array}{l}\text { Social sciences } \\
\text { (economics, } \\
\text { sociology, policy, } \\
\text { law) }\end{array}$ & $14 \pm 5.7$ & 22 \\
\hline
\end{tabular}

SRM leadership (represented in this study by those who serve on SRM committees), it is relevant to understand how these professionals rank the importance of various rangeland products for themselves and how they perceive society ranks the importance of these rangeland products. Therefore, the rankings of perceived relative importance of rangeland products to society are very relevant to how rangelands are managed and what type of training is needed by students to become effective rangeland managers. The survey population was dominated by members who are currently employed in some aspect of rangeland management, research, or teaching (Table 1); therefore, they are uniquely well informed regarding the various rangeland products that society is currently demanding. Since perspectives on "best" and "optimum" tend to be value laden, it is useful to also understand how survey respondents ranked the relative importance of various rangeland products from their own point of view since that perspective can also influence the perception of how rangeland science students should be trained.
Change and the ramifications of change have been a long-running and contentious topic of discussion within the SRM. Faculty and university administrators need to make decisions about how much instruction time can be devoted to a particular topic and which types of expertise should be sought when hiring new faculty. It is appropriate that SRM should provide feedback to help guide these changes in education since the trajectory of change will strongly influence the knowledge base of future rangeland professionals. By virtue of their current active involvement on SRM committees, this survey population is particularly involved with their professional society and therefore presents an important perspective to consider when contemplating the evolution of rangeland science university programs.

Perception of the SRM survey respondents regarding ranking of rangeland products importance to society closely paralleled a ranking provided by a cross section of students at the University of Wyoming campus. However, these rankings of what society desires from rangelands were substantively different from the ranking of what rangeland science graduates were perceived to be most prepared to manage. Current graduates are strongly perceived to be prepared for managing livestock: $66 \%$ of employment supervisors (ie, those who are likely to hire rangeland science graduates) and $60 \%$ of university faculty indicated that they believed that recent science graduates were best prepared to manage livestock. Since livestock was judged to be of low-ranking importance on the continuum of what society seeks from rangelands, this may be placing our current graduates at a competitive disadvantage in the job market when the search image for a job is focused on managing rangeland products in higher demand by society. "Range professionals will be out of business if livestock grazing continues to be their primary target. Our every professional thought must be for the care of the land and water under whatever use society demands," thereby preserving management options for future generations. ${ }^{9}$

The responses to the questions profiled in Tables 2 and 3 illustrate that perspectives on the relative importance of rangeland products is quite diverse, which is reflected in the large variance of the response averages. On the positive side, this wide spectrum of rangeland product priorities affirms that SRM is attracting members with a variety of interests. However, the skewed, bimodal nature of many of the responses illustrated a strong divergence of opinions on some topics, such as the relative importance of livestock as a rangeland product. This is germane to the context of SRM accreditation because the viewpoints of the members influence what they think rangeland science students should be emphasizing in their studies.

The subject emphasis in the range science education programs is reflected in how rangeland science graduates are perceived. Since society demands multiple products from rangeland, it seems like an ideal new graduate would have a skill set reflecting society's priorities. The diverse listing of 
Table 9. Percentage of responses to question posed as "In terms of aiding a successful start to a career, how important is natural resource-related work experience gained prior to graduation? (please check one)"

\begin{tabular}{|c|c|c|c|c|}
\hline Job description & Essential & $\begin{array}{l}\text { Highly } \\
\text { desirable }\end{array}$ & $\begin{array}{l}\text { Moderately } \\
\text { desirable }\end{array}$ & $\begin{array}{c}\text { Makes little to no } \\
\text { difference }\end{array}$ \\
\hline \multicolumn{5}{|l|}{ Government agency } \\
\hline Resource manager $(n=128)$ & 41 & 51 & 8 & 0 \\
\hline Researcher $(n=32)$ & 25 & 66 & 9 & 0 \\
\hline University faculty $(n=77)$ & 29 & 59 & 9 & 3 \\
\hline \multicolumn{5}{|l|}{ Private } \\
\hline Consultant $(n=27)$ & 42 & 50 & 8 & 0 \\
\hline Rancher $(n=19)$ & 82 & 18 & 0 & 0 \\
\hline Other $(n=6)$ & 33 & 67 & 0 & 0 \\
\hline Weighted average & 39 & 53 & 7 & 1 \\
\hline \multicolumn{5}{|l|}{$\begin{array}{l}\text { Character of interaction with } \\
\text { students and recent graduates }\end{array}$} \\
\hline Supervisor ( $n=126)$ & 43 & 52 & 5 & 0 \\
\hline Coworker $(n=47)$ & 36 & 53 & 11 & 0 \\
\hline University faculty $(n=76)$ & 29 & 59 & 9 & 3 \\
\hline No contact $(n=40)$ & 47 & 43 & 10 & 0 \\
\hline
\end{tabular}

Table 10. Percentage of responses to question posed as "How important is it to include the word 'range' or 'rangeland' in the degree title or option designation identified on the student's transcript? (please check one)"

\begin{tabular}{|c|c|c|c|c|}
\hline Job description & Essential & $\begin{array}{l}\text { Highly } \\
\text { desirable }\end{array}$ & $\begin{array}{l}\text { Moderately } \\
\text { desirable }\end{array}$ & $\begin{array}{l}\text { Makes little to } \\
\text { no difference }\end{array}$ \\
\hline \multicolumn{5}{|l|}{ Government agency } \\
\hline Resource manager $(n=128)$ & 24 & 53 & 13 & 10 \\
\hline Researcher $(n=32)$ & 3 & 41 & 25 & 31 \\
\hline University faculty $(n=75)$ & 29 & 27 & 24 & 20 \\
\hline \multicolumn{5}{|l|}{ Private } \\
\hline Consultant $(n=27)$ & 19 & 23 & 31 & 27 \\
\hline Rancher $(n=19)$ & 23 & 18 & 47 & 12 \\
\hline Other $(n=5)$ & 40 & 0 & 40 & 20 \\
\hline Weighted average & 23 & 39 & 21 & 17 \\
\hline \multicolumn{5}{|l|}{$\begin{array}{l}\text { Character of interaction with } \\
\text { students and recent graduates }\end{array}$} \\
\hline Supervisor $(n=126)$ & 20 & 41 & 21 & 18 \\
\hline Coworker $(n=47)$ & 28 & 53 & 13 & 6 \\
\hline University faculty $(n=75)$ & 28 & 28 & 21 & 23 \\
\hline No contact $(n=40)$ & 17 & 35 & 35 & 13 \\
\hline
\end{tabular}


topics considered important for a range management curriculum reflects the broad education that would be required for multiple-use management of rangelands. Unfortunately the perception of what the rangeland graduates are viewed as most capable of doing is not well matched with the priority for products that society wants. It is reasonable to assume that since government land managers must strive to provide a mix of rangeland products sought by society, they would be most inclined to seek new hires who they perceive are better prepared to manage for the multiple objectives of rangeland management sought by society. The fact that $66 \%$ of employee supervisors and $60 \%$ of the faculty thought rangeland science graduates are best prepared for managing the livestock component of rangeland products no doubt has some impact on hiring decisions. It needs to be determined whether this perception is correct. If the perception is correct, conservation biologists, ecologists, hydrologists, and recreation scientists will likely be increasingly hired to fill the perceived void in what rangeland science graduates are prepared to do with their education. If it is not correct, we have a problem of communication/education of employers, not a curriculum problem.

A clue to why the perception persists that livestock are central to the image of rangeland management may be reflected in the response to the question requesting a ranking of which rangeland products were most important to the survey respondent. The profiles of this personal ranking from the survey did not provide a good overlap with the same respondents' rankings of what society was perceived to want from rangelands. Livestock was the most polarizing, receiving a mode ranking of \#1 of what was most important to survey respondents but receiving a mode ranking of \#5 in the feedback regarding societal perception and University of Wyoming student perception. Heady expressed concern that "our non-member public still believes that 'SRM is a livestock society."' Perhaps a reason for this continuing perception is that many members indirectly communicate their personal livestock product preferences to a broader society that increasingly believes that "commodity uses of the nation's lands are unnatural, undesirable and should be reduced." $"$

Although many respondents ranked livestock as a very high priority to them, personally, there was a sizable minority who ranked livestock importance to them as very low. This disparity of viewpoints was reflected by the mean and median being widely separated from the mode and resulted in a relatively large standard-error term for the responses.

The fact that the skill level needed by rangeland professionals (Table 6) was more strongly related to personal rankings than perceived societal rankings of rangeland product priorities illustrates the role that personal bias plays in curriculum formulation. That said, the subjects that received the highest rankings had the lowest variance in response, indicating a shared vision about what are considered to be the most important elements of a rangeland science education program. Another way to get at what are judged to be the most important elements of a rangeland management curriculum was to ask an open-ended question where the reader lists the 3 most important skills that a rangeland science program should teach. The pattern of rankings (Table 6) and the responses to the open-ended question (Table 7) followed a similar pattern. The fact that various elements of ethics (work ethic, land ethic, personal ethic) or leadership were rarely mentioned is troubling. Leadership and ethics are an important component of curriculums in fields such as business or military service but apparently rarely come to mind when thinking about skills taught in a rangeland science program.

Feedback on the split between what a curriculum should emphasize was fairly consistent from the different job categories or the nature of contact with students. In particular, respondents from most different background groupings favored a fairly even split between resource management and fundamental scientific processes, with both being suggested to compose about $30 \%$ of the curriculum (ranchers were the exception, expressing that $46 \%$ of the curriculum emphasis should be on resource management and only $18 \%$ on natural sciences). This goal for balance can be viewed as a fulcrum representing the spectrum of rangeland ecology and management interests.

\section{Fundamental Science} Management

Over the past several decades, it has become increasingly difficult for rangeland programs to maintain a balance in emphasis between management and fundamental science. This balance will be harder to maintain in the future because the greatest potential for fiscal growth of research universities is determined by the success of professors competing for grants (and the indirect cost return to the university administration that comes with the grants). Research grant opportunities are much more available to those working on fundamental scientific and large-scale ecological processes rather than ranch-level management. Consequently, as professors who emphasized rangeland management in their careers retire, there is great pressure by university administrators to replace them with individuals more attuned to focusing on specialized elements of science with high grantsmanship potential regardless of the lip service paid to interdisciplinary and applied research. This implies that university administrators will be likely to advocate either that rangeland management positions be converted to expand the faculty in other, often unrelated basic-science disciplines or that range resource programs shift the emphasis of their hires toward fundamental (basic) scientific research. The change in faculty emphasis tends to be reflected in the way courses are taught, the types of elective courses that are offered, and ultimately the types of students 
who are produced. Another casualty of a growing emphasis on grantsmanship within universities is that the time needed to write and implement grants tends to be at odds with the large amount of time needed to grade term papers and problem sets. In support of this concern, the authors are not aware of a range program at any university that currently devotes the time to communication and quantitative skills that was suggested by the survey respondents.

Employers focused on management objectives may be frustrated by an imbalance in management and fundamental science instruction and may be disappointed by the low proficiency in communication and quantitative skills mastered by graduates, but, given the other candidates available in the job pool, they are still likely to hire the range graduates. These trends/concerns are not unique to rangeland management; the same trends are observed in other resource management professions as well. ${ }^{10}$ Since the management tasks will still need to be done, the implication is that management-oriented employers can expect to spend more time and money on targeted continuing education programs tailored to meet their needs. This is likely to be a daunting task since many management-oriented employers do not have time and money to spare. Therefore, employers have a strong vested interest to work to ensure that their education needs and priorities are met by universities. This can be effectively done through the professional societies such as the SRM.

\section{A Way Forward}

How can professional societies work with universities and employers to make sure that the next generation of resource management graduates will receive an education that will provide a sound foundation of skill and insight? Accreditation and certification are the 2 methods most frequently employed. Of the 2 methods, certification tends to focus on mastery of technical skills that can be evaluated through a test format, perhaps supplemented by a minimum requirement of experience. However, accreditation is more suitable if the goal is to make sure that students have been exposed to the spectrum of issues covered by Scarnecchia's definition of range management science: "much more than being simply applied ecology, land management or people management, it is a management science that should be designed to investigate, analyze, integrate and communicate multiple objectives, variables, interactions, values, and behaviors of complex systems, that involve, broadly, rangeland."11

A prerequisite to either the certification or the accreditation process being effective is that employers must reinforce the education goals expressed by their professional society by providing a substantive premium in the hiring process to students who graduate from accredited universities. If this feedback loop is in place, universities have a vested self-interest to make sure that they are structured to meet certification or accreditation goals. Many disciplines use one or both of these techniques very effectively (eg, engineering programs, veterinary programs). Currently this is not the case for rangeland management science. Perhaps the revision of the SRM accreditation process and the feedback harvested in this survey will serve as initial steps toward helping SRM refine their accreditation standards for range programs. We hope that the issues documented in this survey will contribute to discussions within universities regarding the evolving content of their range science curricula.

\section{Acknowledgments}

This research was supported by the USDA-CSREES award 2006-38832-03678. The authors thank A. P. Thurow and M. D. Pollock for their contributions to this article and thank the respondents to the survey.

\section{References}

1. McClaran, M. P. 2000. History of the range curriculum: are there new trails? Rangelands 22(6):23-27.

2. Sampson, A. W. 1919. Suggestions for instruction in range management. Journal of Forestry 17:523-545.

3. Malechek, J. C. 1992. Administrative considerations in range education. In: J. P. Dobrowolski [сомp.]. Rangelands 14(3):142-144.

4. Sснаснт, W. H., And M. L. McInnis. 2003. Status of undergraduate education in range science in the USA. Journal of Natural Resources and Life Sciences Education 32:57-60.

5. Frasier, G. 2006. Readers of Rangelands survey results. Rangelands 28(6):25-27.

6. Albrecht, S. W. 2003. Demographics of the Society for Range Management. Rangelands 25(3):3-6.

7. Pollock, M. D. 2007. Personal communication-data from in-progress dissertation research. Laramie, WY: Department of Rangeland Ecology and Management, University of Wyoming.

8. Holechek, J. L., R.D. Pieper, and C. H. Herbel. 2004. Range management: Principles and practices. Upper Saddle River, NJ: Person Education.

9. Heady, H. F. 1999. Perspectives on rangeland ecology and management. Rangelands 21(5):23-33.

10. Scalet, C. 2006. Dinosaur ramblings. Wildlifer's Log 65(1): 3-8.

11. Scarnecchia, D. L. 2003. Empowering diversity: envisioning, designing, and development range management science. Journal of Range Management 56(6):558-569.

Authors are Professor, Department of Rangeland Ecology and Watershed Management, University of Wyoming, Laramie, WY 82071, tthurow@uwyo.edu (Thurow); Professor,Department of Ecosystem Science and Management, Texas A\&M University, College Station, TX 77843 (Kothmann); Research Scientist, Eastern Oregon Agricultural Research Center, Oregon State University, PO Box E, Union, OR 97883 (Tanaka); and National Program Leader for Rangeland and Grassland Ecosystems, USDA-CSREES, 1400 Independence Ave, SW, Washington, DC 20250 (Dobrowolski). 